\title{
Muslim Scholars, Islamic Studies, and the Gendered Academy
}

The International Institute of Islamic Thought (IIIT) hosted its fourth annual Ismail Al Faruqi Memorial Lecture at the 2017 annual meeting of the 
American Academy of Religion (AAR). The presentation took place at the Hynes Convention Center in Boston on Sunday, November 19, 2017. Dr. Kecia Ali (Boston University, Department of Religion) delivered the keynote lecture, titled "Muslim Scholars, Islamic Studies, and the Gendered Academy." In her speech, Dr. Ali situated ongoing and gendered contestations in Islamic Studies within a number of broader contexts: the history of the AAR (currently the largest American organization dedicated to the study of religion), contemporary crises in higher education, and our shifting national climate.

Professor Ali began her talk by recalling a 2005 lecture she delivered at Loyola University, focused on the topic of gender and Quran interpretation. During the Q\&A, a Muslim man in the audience unaffiliated with the university questioned whether her scholarly approach-grounded in a feminist methodology - was appropriate for apprehending the Islamic tradition. He cited The Tao of Islam: A Sourcebook on Gender Relationships in Islamic Thought-a work he attributed to William Chittick-to make his case: Islam necessarily involves the equal treatment of the masculine and feminine. While Dr. Ali briefly noted her skepticism towards the text in question, the most striking aspect of her account of this encounter was the question of citation. It was in fact Chittick's wife-Sachiko Murata-who wrote The Tao of Islam, not Chittick. While Dr. Ali chose not to unpack the multilayered implications and assumptions woven into her interlocutor's intervention, she dwelled on the gendered impacts of such misattributions.

Before returning to this discussion, Dr. Ali devoted time to situating the AAR within the contemporary moment. She traced the origins of the AAR to 1909, when it emerged as a Protestant organization called the National Association of Biblical Instructors (NABI). It was only in the 1960s, after a number of internal debates, that the organization assumed its current title. This shift, however, came with new challenges and debates: Was the AAR to welcome only theological and confessional approaches to the study of religion? What of critical-analytical and political approaches? Professor Ali-an AAR member of almost two decades-emphasized that the assumed bifurcation between the two continues to represent a wider problem.

As Muslims became increasingly involved with the AAR after the 1960s, criticisms arose from two parties simultaneously: non-Muslim academics concerned about maintaining 'non-biased' scholarship, and Muslims worried about the potential for "inappropriately constructive Islamic theological work" taking place outside of conventional centers of Islamic 
learning. The latter worried AAR would be "run by a cabal of progressive Muslims with activist agendas," and some even went so far as to decry the alleged heterodoxy (and sometimes even "apostasy") of Muslim scholars affiliated with the AAR. The conservative critics of the former category instead emphasized the necessity of "safely critical" studies of religion, characterized by supposed moral neutrality and analytical distance. Dr. Ali problematized these accounts by demonstrating the (gendered) workings of power in both contexts.

Beyond challenges within the AAR, the general decline in public research funding, the crisis of "adjunctification", recent threats to Title IX protections, and the shortage of tenure-track positions are all issues that disproportionately and negatively impact women in the academy. Through mechanisms like gatekeeping tenure committees, ever-changing "standards of excellence", all-male panels, and discriminatory funding practices, the (neo)liberal university maintains itself as a site of institutionalized sexism. Out of these mechanisms, Dr. Ali specifically elaborated on what has been termed the "two-body problem".

The two-body problem refers to an issue frequently faced by couples in academia, who can neither secure jobs at the same university nor at two universities within reasonable commuting distance of one another. Thus one member of the couple may be forced to abandon his or her hopes for an academic career. Dr. Ali noted how such problems with university hiring - along with issues of adequate child care, and the distribution of work and service within academic departments-are systemic and gendered problems rather than individual struggles to be overcome on a case-bycase basis. However, as Dr. Ali suggested, to speak only of the bureaucratic measures by which the gendered academy reproduces itself is to under-emphasize other sites of contestation, including recent and ongoing public accusations of sexual harassment, abuse, assault, and rape within and beyond the academy.

The most technical part of Dr. Ali's talk, however, focused on the politics of citation. In this portion of the lecture, Professor Ali discussed four books by three well-known Muslim male scholars and noted the shockingly low citation of female scholars (Muslim and otherwise) in each. In one case, female authors comprised a little over $1 \%$ of the works cited. Dr. Ali asserted that the widespread tendency to frame the findings of Islamic Gender Studies and its emerging canon as 'common sense' highlights the devaluation of women's scholarly (and other) work. 
Dr. Ali traced this form of devaluation in media representations of Lois Lamya Al Faruqi-the late musician, expert on Islamic art, and professor at Temple University. By displaying a number of newspaper headlines from the 1980s, Dr. Ali demonstrated the ways Dr. Faruqi's scholarly contributions-but also women's academic contributions more broadly-appeared to dissolve. Indeed, few journalistic references to Ismail Al Faruqi (a co-founder of IIIT and the Study of Islam Unit at AAR) mention Lamya $\mathrm{Al}$ Faruqi, while in contrast, references to Lamya Al Faruqi represent her accomplishments as peripheral and sometimes even invisible compared to those of her husband. By centering the voice of Lamya al Faruqi, Dr. Ali redefined IIIT's annual Al Faruqi Memorial Lecture and situated it within ongoing and timely conversations in Islamic Studies focused on gender, power, and justice.

Muneeza Rizvi

$\mathrm{PhD}$ Candidate

Department of Anthropology

University of California, Davis 